\title{
Perubahan Perladangan Menjadi Perkebunan dan Dampaknya Terhadap Kebakaran Hutan dan Lahan di Provinsi Riau
}

\section{The changes from Swidden Agriculture to Plantation and Its Impact on Forest and Land Fires in Riau Province}

Efral Derik $^{\mathrm{a}}$, Didik Suharjito ${ }^{\mathrm{b}}$, Lailan Syaufina $^{\mathrm{c}}$

aProgram Studi Ilmu Pengelolaan Hutan, Sekolah Pascasarjana, Institut Pertanian Bogor, Kampus IPB Darmaga, Bogor, 16680, Indonesia

${ }^{b}$ Departemen Manajemen Hutan, Fakultas Kehutanan, Institut Pertanian Bogor, Kampus IPB Darmaga, Bogor, 16680, Indonesia ${ }^{\mathrm{c}}$ Departemen Silvikultur, Fakultas Kehutanan, Institut Pertanian Bogor, Kampus IPB Darmaga, Bogor, 16680, Indonesia

\section{Article Info:}

Received: 07 - 03 - 2018

Accepted: 09 - 06 - 2018

\section{Keywords:}

Adoption of innovations, cultural change, forest and land fires.

\section{Corresponding Author:}

Efral Derik

Program Studi Ilmu Pengelolaan Hutan, Sekolah Pascasarjana, Institut Pertanian Bogor,

Kampus IPB Darmaga, Bogor, 16680, Indonesia;

Email: efral.derik@yahoo.co.id

\begin{abstract}
Swidden agriculture is often blamed for forest and land fires. Meanwhile, swidden agriculture do not always cause forest and land fires because the community apply their local knowledge. This study aims to describe the changes of swidden agriculture practices to plantation, and explain the impact of the swidden agriculture and plantation practice on forest and land fires in Riau Province. This study uses theory of cultural change and theory of adoption of innovations guidance to explain the phenomenon. The survey method was used to collect data by interviewing respondents. Observation and collection of secondary data were done. The results of this study show that during swidden agriculture did not cause forest and land fires. Land fires occurring during plantation prac-tices indicate that clearing of plantation land is one of the causes of forest and land fires. The adoption of modern technology in the preparation of farmer farmlands needs attention from stakeholders.
\end{abstract}

How to cite (CSE Style $8^{\text {th }}$ Edition):

Derik E, Suharjito D, Syaufina L. 2019. Perubahan Perladangan Menjadi Perkebunan dan Dampaknya Terhadap Kebakaran Hutan dan Lahan di Provinsi Riau. JPSL 9(2): 314-325. http://dx.doi.org/10.29244/jps1.9.2. 314-325.

\section{PENDAHULUAN}

\section{Latar Belakang}

Kebakaran hutan dan lahan terjadi hampir setiap tahun di Indonesia. Pada tahun 1997 kebakaran hutan untuk pertama kali dinyatakan sebagai bencana nasional, kebakaran terus terjadi pada tahun 1998 dengan penyebab utamanya adalah pembukaan lahan besar-besaran (KemenegLH dan UNDP 1998). World Bank mencatat bahwa kejadian kebakaran hutan dan lahan pada tahun 2015 mengakibatkan kerugian negara 200 trilyun lebih (Purnomo et al. 2017). Kebakaran hutan dan lahan yang melanda beberapa provinsi di Indonesia, termasuk Provinsi Riau yang merupakan salah satu provinsi rawan kebakaran yang ditunjukkan dengan terjadinya kebakaran hutan dan lahan (Saharjo 2016; Adiputra dan Barus 2018), yang meliputi hampir seluruh kabupaten/kota dan Kabupaten Siak merupakan salah satu kabupaten dengan jumlah hotspot yang banyak (Syaufina 2014). 
Penggunaan api dalam perladangan sebagai ciri khasnya sering dikaitkan dengan kebakaran hutan dan lahan. Api digunakan untuk penyiapan lahan pada perladangan tradisional yang berpindah-pindah merupakan salah satu penyebab utama kebakaran hutan dan lahan (Rasyid 2014). Hotspot merupakan alat untuk mendeteksi kebakaran hutan dan lahan. Hotspot yang terlihat di luar areal kerja perizinan kehutanan yang diasumsikan adanya pembukaan lahan untuk ladang di Kotowaringin Timur (Amril 2009).

Perladangan telah menjadi bagian penting dalam sejarah pengelolaan hutan dan lahan di Indonesia. Dove (1985) menyatakan bahwa masyarakat Indonesia mengandalkan kehidupannya dari perladangan. Perladangan dipraktikkan di banyak tempat seperti di Kabupaten Kotawaringin Timur (Amril 2009), Kabupaten Yapen Waropen (Irjayani 2000), Kabupaten Kutai Kartanegara, Kutai Timur, dan Kutai Barat (Pardosi et al. 2005) Kabupaten Sanggau (Kuswandi 2006), dan Kabupaten Kotabaru (Rahmawati dan Susilawati 2012). Meskipun perladangan banyak dipraktikkan di berbagai tempat, namun praktik perladangan telah ditinggalkan di Kuta Gamber Karo dengan alasan masyarakatnya lebih memilih berkebun tembakau (Singarimbun 1984).

Dengan menggunakan pengetahuan lokal, pembukaan lahan untuk ladang dilakukan secara terbatas dan terkendali sehingga tidak menyebabkan kebakaran hutan dan lahan (Goethals 1984; Hudson dan Hudson 1984; Dove 1985; Rahmawati dan Susilawati 2012). Di samping dilakukan secara turun-temurun, kegiatan berladang misalnya dalam penyiapan lahan dilakukan bersama-sama seperti pembakaran yang dilakukan secara serentak (Ahmad, 2000).

Penelitian Evayanti dan Zulkarnaini (2014) menunjukkan hubungan positif dan signifikan partisipasi masyarakat peduli api dengan pencegahan dan pengendalian kebakaran hutan dan lahan di Kabupaten Pelalawan Provinsi Riau, atau penelitian Prasasti et al. (2012) yang menjelaskan mengenai pemanfaatan informasi jumlah hotspot dalam pendugaan areal yang terbakar termasuk penelitian Hanifah et al. (2016) melihat dari pengamatan visual piksel citra yang menunjukkan kondisi pada saat sebelum kebakaran (pre fire) dan setelah kebakaran (post fire). Penelitian Molyoutami et al. (2010) menjelaskan bahwa integrasi masyarakat marjinal di Indonesia dengan pasar telah menghasilkan perubahan lahan bera perladangan menjadi sistem agroforestry.

Hasil penelitian-penelitian terdahulu seperti yang diuraikan di atas menunjukkan bahwa penggunaan api dalam kegiatan perladangan dapat menyebabkan kebakaran hutan dan lahan, namun dalam kasus-kasus lain tidak menimbulkan kebakaran hutan dan lahan. Penelitian-penelitian terdahulu belum ada yang menjelaskan perubahan penggunaan api dalam praktik pertanian. Fokus penelitian ini adalah tentang perubahan praktik pertanian dari perladangan ke perkebunan. Penelitian ini bertujuan untuk menjelaskan perubahan praktik pertanian dari perladangan ke perkebunan dan implikasinya terhadap penggunaan teknologi api dan organisasi sosial, serta dampaknya terhadap kebakaran hutan dan lahan; dan menjelaskan alasan-alasan perubahan, mengapa melakukan perubahan teknologi dan organisasi, dan perubahan dari perladangan menjadi perkebunan.

\section{METODE}

\section{Kerangka Teori Penelitian}

Penelitian ini menggunakan teori perubahan budaya dari Steward (1955) dan teori adopsi inovasi dari Rogers (1983). Steward menyatakan bahwa lingkungan yang berbeda menyebabkan perbedaan bentuk organisasi, dan teknologi yang digunakan. Perbedaan lingkungan misalnya pada lingkungan dengan jenis hewan buruan yang berbeda dapat membedakan jenis peralatan dan teknologi yang digunakan, termasuk organisasi dalam berburu yang dilakukan secara berkelompok atau perorangan. Penelitian ini menunjukkan perbedaan lingkungan. Lingkungan perladangan berbeda dengan lingkungan perkebunan. Praktik perladangan berubah menjadi praktik perkebunan. Perubahan ini menyebabkan perbedaan teknologi yang digunakan dan organisasinya. Rogers menjelaskan bahwa adopsi inovasi merupakan proses penerimaan sesuatu yang baru 
yang ditawarkan dan diupayakan oleh pihak lain dengan adanya perubahan sikap, pengetahuan dan perilaku. Pada penelitian ini perubahan perilaku ditunjukkan dengan adopsi teknologi dan organisasi sosial. Penggunaan teknologi dan organisasi dalam perubahan perladangan menjadi perkebunan mempengaruhi kebakaran hutan dan lahan.

\section{Waktu dan Tempat Penelitian}

Penelitian ini dilaksanakan selama tiga bulan dari bulan Mei sampai Juli 2017. Penelitian lapangan dilakukan di Kampung Olak dan Kampung Sungai Rawa Kabupaten Siak Provinsi Riau. Pemilihan lokasi penelitian dilakukan secara purposive dengan pertimbangan Kabupaten Siak beberapa tahun lalu hampir setiap tahun terjadi kebakaran hutan dan lahan, serta masyarakat asli Riau yaitu suku Melayu banyak menempati kabupaten ini, sehingga bisa mengkaji perubahan perladangan menjadi perkebunan di masyarakat. Kampungkampung tersebut dipilih dengan pertimbangan (1) Kampung Olak yang tidak rawan terjadi kebakaran hutan dan lahan, dan (2) Kampung Sungai Rawa termasuk kampung rawan terjadi kebakaran hutan dan lahan (DitPKHL, 2017), termasuk mengadopsi teknologi, atau mematuhi peraturan perundang-undangan.

\section{Analisis Data}

Penelitian ini menggunakan metode survai. Data dikumpulkan melalui wawancara dengan responden dengan menggunakan kuesioner. Responden merupakan rumah tangga petani yang dipilih yaitu petani yang membuka dan menyiapkan lahannya. Berdasarkan pendataan terhadap populasi petani yang membuka dan menyiapkan lahan, terdapat 104 rumah tangga petani di Kampung Olak dan 72 rumah tangga petani di Kampung Sungai Rawa. Pemilihan responden dilakukan dengan mengambil sampel 30 petani pada masingmasing kampung. Sampel $10 \%$ dari populasi dianggap jumlah minimal pada penelitian deskriptif (Silalahi 2012). Jumlah sampel pada penelitian ini lebih besar dari $10 \%$ populasi. Data yang dikumpulkan melalui wawancara dan observasi lapang, dan data sekunder dipadukan dan dianalisis dengan menggunakan analisis statistik deskriptif dan uji statistik non parametrik Rank Spearman (rs).

\section{HASIL DAN PEMBAHASAN}

\section{Praktik Perladangan}

Praktik perladangan di Kampung Olak dan Sungai Rawa berlangsung sejak masa awal adanya kampung tersebut. Kampung Olak sudah ada pada tahun 1936 dan Kampung Sungai Rawa pada tahun 1940. Aktivitas penyiapan lahan untuk perladangan dilakukan dengan menebang pohon-pohon atau semak belukar dan membakarnya, bertujuan agar lahan siap untuk ditanami padi. Hasil ladang berupa padi ladang merupakan kebutuhan pokok masyarakat. Selain menanam padi, masyarakat juga menanam sayur-sayuran dan karet. Penanaman padi sebagai hasil jangka pendek dan tanaman karet sebagai hasil jangka panjang. Hal ini menunjukkan bahwa praktik perladangan sudah menjadi tradisi masyarakat di Kampung Olak dan Sungai Rawa yang diturunkan dari generasi ke generasi (Suharjito 2011).

Pada penelitian ini pengetahuan petani dalam perladangan meliputi beberapa kegiatan seperti pemilihan lokasi ladang, penebasan dan penebangan, pembakaran, penjagaan, dan pemanenan. Petani Kampung Olak memilih lokasi ladang bukan di lahan gambut. Ladang dibuka dengan luas maksimal dua ha. Petani Kampung Olak menggunakan istilah luas dua suku untuk ukuran luas yang sama dengan satu ha. Keterbatasan kemampuan petani mengerjakan lahan merupakan alasan penyiapan lahan ladang tidak lebih dari dua ha. Sama halnya dengan di Kampung Olak, petani Kampung Sungai Rawa tidak memilih lahan gambut sebagai lokasi ladang. Ladang dipilih pada lokasi bertanah mineral. Petani Kampung Sungai Rawa menggunakan istilah luasan ladang yang berbeda dengan petani di Kampung Olak. Istilah yang lazim digunakan yaitu jalur. Jalur 
merupakan satuan ukuran lahan dengan ukuran $17 \mathrm{~m}$ x $170 \mathrm{~m}$. Dengan luasan seukuran jalur, petani mampu membuka ladang seluas dua atau tiga jalur, sampai maksimal dengan luas satu ha. Kemampuan petani Kampung Olak dan Sungai Rawa dalam membuka lahan perladangan menunjukkan kemiripan dengan ladang yang dibuka oleh Suku Dayak Kahayang di Kalimantan Barat seluas 1.28 hingga 2.4 ha (Syaufina 2008). Penggunaan istilah yang berbeda menunjukkan pengetahuan lokal yang berbeda antara satu daerah dengan daerah yang lain. Hal ini juga ditunjukkan dengan penggunaan istilah luasan ukuran ladang yang berbeda pada perladangan Suku Dayak Kahayang dengan menggunakan istilah gentang (Syaufina 2008).

Penyiapan lahan perladangan diawali dengan penebasan dan penebangan kemudian dilanjutkan dengan pembakaran. Penebasan dilakukan dengan memotong semak-semak dan kayu-kayu kecil yang ada di hutan. Penebangan dilakukan terhadap pohon-pohon yang besar. Salah satu cara menebang yaitu dengan membuat takik rebah pada semua pohon yang akan ditebang, kemudian dipilih pohon besar untuk ditebang yang akan jatuh ke pohon berikutnya, sehingga pohon bisa tumbang secara berurutan. Cara penebangan tersebut dilakukan pada sore hari ketika petani akan pulang ke rumah. Cara penebangan seperti ini juga dilakukan oleh Orang Kantu' di Kalimantan Barat dengan istilah reaksi-berantai (Dove 1985).

Peralatan yang digunakan pada penyiapan lahan perladangan seperti parang, kapak dan beliung. Parang digunakan untuk memotong semak-semak dan pohon yang kecil, sedangkan kapak dan beliung digunakan untuk menebang pohon berdiameter besar. Beliung merupakan peralatan yang sudah lama digunakan petani Kampung Olak dan Sungai Rawa. Beliung memiliki tangkai yang terbuat dari jenis kayu tertentu yang dalam penggunaannya membuat beliung bisa memantul-mantul sehingga memudahkan penebangan pohon. Penggunaan beliung untuk menebang pohon pada kegiatan perladangan juga dilakukan oleh Orang Kantu' di Kalimantan Barat, beliung disebut kapak dayak (beliyong) (Dove 1985).

Pembakaran pada penyiapan lahan perladangan dilakukan setelah penebangan selesai. Jarak waktu antara penebangan dan pembakaran disebut masa tunggu. Waktu yang diperlukan pada masa tunggu sekitar satu sampai tiga bulan. Pembakaran dilakukan setelah melewati masa tunggu tersebut. Material hasil penebasan dan penebangan seperti semak-semak dan kayu-kayu dengan kondisi kering karena telah melewati masa tunggu pada musim kemarau. Pembakaran dianggap sebagai pilihan cara yang paling efektif untuk membuka lahan perladangan. Pembakaran harus menghanguskan seluruh material yang terdapat di calon ladang. Pembakaran yang tidak menghanguskan menyebabkan ladang tidak bisa ditanami padi. Penggunaan api dalam penyiapan lahan perladangan bertujuan agar lahan bersih untuk ditanami, tersedianya pupuk sebagai unsur hara tanaman dari hasil pembakaran. Sehingga keberhasilan ladang sangat tergantung dengan keberhasilan pembakaran. Ladang yang terbakar bersih merupakan pertanda baik bagi panen yang baik (Goethals 1984) dan sukses atau gagalnya panen padi terutama ditentukan oleh sukses atau gagalnya proses pembakaran (Dove 1985).

Sebelum pembakaran dilakukan, terlebih dahulu dibuat sekat bakar di sekeliling lahan yang akan dibakar. Sekat bakar dibuat agar api tidak merembet ke tempat yang lain. Ukuran sekat bakar dibuat selebar kira-kira dua m. Pembakaran dimulai sekitar pukul 13:00 waktu setempat. Keuntungan membakar pada waktu ini adalah material hasil dari penebasan dan penebangan akan cukup kering karena telah terkena sinar matahari sejak pagi hari. Petani Kampung Olak dan Sungai Rawa melakukan pembakaran pada bulan Juli atau Agustus. Selain memperhitungkan waktu pembakaran, petani juga memperhitungkan arah angin. Arah angin akan turut menentukan sisi ladang yang menjadi titik dimulainya pembakaran. Pembakaran ladang dilakukan dengan menggunakan kayu panjang yang dibuat seperti obor. Tangkai obor berupa kayu dengan panjang sekitar dua $\mathrm{m}$. Penggunaan obor yang terbuat dari potongan-potongan bambu atau bagian kulit pohon tua yang tergulung digunakan oleh orang Kantu' di Kalimantan sebagai alat utama selama pembakaran (Dove 1985).

Pembakaran pada praktik perladangan tidak menyebabkan api merembet ke tempat yang lain. Pada proses pembakaran, petani menjaga api yang membakar calon ladang. Selain itu, pada masa praktik perladangan, sebagian besar areal di sekitar batas ladang merupakan hutan. Pembakaran tidak menimbulkan banyak asap. Hal ini disebabkan oleh pembakaran yang sempurna. Pembakaran yang sempurna menyebabkan api berkobar dengan hebat, karena api membakar material yang telah kering. Periode waktu pembakaran dalam praktik 
perladangan di Kampung Olak dan Sungai Rawa pada bulan-bulan tertentu, juga dipraktikkan di daerah lain dengan periode waktu tertentu pula. Misalnya masyarakat Kampung Rarak Sumbawa Barat melakukan pembakaran mulai pertengahan Oktober sebelum hujan-hujan barat jatuh (Goethals 1984) atau di Desa Telang Kalimantan Tengah yang melakukan pembukaan dan pembakaran ladang antara bulan Juni dan September (Hudson dan Hudson 1984).

Setelah kegiatan penebasan, penebangan dan pembakaran dilakukan, selanjutnya lahan ditanami padi. Penanaman padi dilakukan dengan membuat lubang dengan cara ditugal. Penanaman padi dilakukan dengan memasukkan 20 hingga 30 benih padi pada setiap lubang yang ditugal. Jarak antar lubang yang ditugal merupakan jarak tanam padi yaitu sekitar $20 \mathrm{~cm}$ atau lebih kurang satu jengkal orang dewasa. Kebutuhan air untuk padi ladang tidak berasal dari pengairan atau irigasi, namun memanfaatkan air hujan. Oleh sebab itu, petani melakukan penanaman ketika musim hujan akan tiba. Petani memperkirakan musim hujan yang akan datang sehingga bisa menyirami ladang yang telah ditanami padi. Penanaman dilakukan pada awal musim hujan pada bulan September. Selain menanam padi, petani juga menanam cabe, timun, dan terong. Penanaman sayuran dilakukan dengan cara menabur bijinya. Jenis komoditas tanaman ladang tidak jauh berbeda dengan yang ditanam oleh masyarakat Ma'anyan di Kalimantan Tengah dengan menanam padi dan tanaman lain seperti nenas, pisang, tebu, ubi kayu, terong, cabe, berbagai macam labu-labuan, gambas dan sayuran (Hudson dan Hudson 1984). Hal tersebut juga dilakukan oleh masyarakat Desa Allang di Provinsi Maluku (Cooley 1984) dan di Kutai Kartanegara (Pardosi et al. 2005).

Setelah ladang ditanami padi, petani melakukan kegiatan penjagaan ladang. Penjagaan ladang bertujuan menghindari serangan hama seperti babi dan burung. Penjagaan ladang diawali dengan pembuatan pagar pada sekeliling ladang. Pemagaran ladang dilakukan oleh pihak laki-laki. Pemagaran membutuhkan waktu yang cukup lama dan kayu yang cukup banyak karena pagar dibuat dengan susunan kayu yang rapat. Penjagaan dengan membuat pagar pada sekeliling ladang juga dilakukan masyarakat Desa Rarak di Sumbawa Barat untuk menjaga ladang dari gangguan babi hutan dan rusa yang datang malam hari (Goethals 1984), termasuk ladang di Desa Allang Provinsi Maluku yang dikelilingi pagar kasar dan kuat yang terbuat dari dahan-dahan bambu (Cooley 1984).

Setelah tanaman padi berumur empat sampai lima bulan, petani melakukan pemanenan padi ladang. Hasil panen dikonsumsi untuk memenuhi kebutuhan rumah tangga petani sendiri. Jika hasil panen padi banyak dan berlimpah, hasil panen tersebut dijual oleh petani. Hasil padi ladang pada lahan seluas dua ha dapat memenuhi kebutuhan padi rumah tangga petani selama satu tahun. Kebutuhan padi setiap rumah tangga petani di Kampung Olak dan Sungai Rawa dipenuhi dari hasil ladangnya, seperti halnya pemenuhan kebutuhan padi yang diperoleh dari ladang untuk setiap jabu atau rumah tangga di Desa Kuta Gamber (Singarimbun 1984).

Petani Kampung Olak dan Sungai Rawa melakukan penyiapan lahan perladangan secara bersama-sama. Petani menyebutnya sebagai gotong-royong. Pembakaran dalam penyiapan lahan perladangan di Kampung Olak disebut "solang bako lahan" yang artinya membakar lahan bersama-sama. Hal ini yang menunjukkan kebersamaan petani dalam penyiapan lahan. Gotong-royong dilakukan petani dengan kegiatan seperti berkumpul terlebih dahulu untuk mendiskusikan letak lahan yang akan dijadikan ladang dan menentukan posisi lahan masing-masing, para petani secara bergantian menyelesaikan suatu lahan dan dilanjutkan mengerjakan lahan petani yang lain, atau petani mengerjakan pekerjaan tertentu untuk pekerjaan yang harus dilakukan secara bersama-sama seperti membuat pagar di sekeliling ladang. Gotong-royong pada praktik perladangan tidak hanya dilakukan petani di Kampung Olak dan Sungai Rawa. Gotong-royong juga dilakukan masyarakat Kantu' di Kalimantan Barat dengan menggunakan tenaga kerja gotong-royong dan tolongmenolong (Dove 1985), masyarakat desa di Sumbawa melakukan gotong-royong di ladang dengan tiga macam bentuk seperti nulong, saleng tulong dan basiru (Goethals 1984), atau gotong-royong masyarakat Ma' anyan yang secara bergiliran membuka lahan setiap anggota masyarakat dengan membentuk kelompok menurut hubungan ketetanggaan atau persahabatan yang terdiri atas 12 atau 15 orang (Hudson dan Hudson 1984).

Petani Kampung Olak dan Sungai Rawa masih menggabungkan istilah gotong-royong dan tolongmenolong. Petani menggunakan istilah gotong-royong untuk seluruh kegiatan yang dilakukan secara bersama- 
sama. Petani belum membedakan penggunaan istilah gotong-royong dan tolong-menolong, sebagaimana Marzali (2005) membedakan gotong-royong dan tolong-menolong. Marzali (2005) menjelaskan bahwa gotong-royong merupakan kegiatan kerja sama untuk menyelesaikan suatu pekerjaan tertentu yang dianggap berguna bagi kepentingan umum, sedangkan tolong-menolong merupakan kegiatan bersama untuk menyelesaikan suatu pekerjaan tertentu yang dianggap berguna bukan bagi kepentingan umum, tapi untuk kepentingan individu tertentu.

Perladangan di kampung Olak dan Sungai Rawa tidak dipraktikkan lagi. Hasil penelitian ini menunjukkan bahwa perladangan berakhir pada waktu yang berbeda, yaitu tahun 2005 di Kampung Olak dan tahun 1980 di Kampung Sungai Rawa. Alasan paling penting petani di Kampung Olak berhenti berladang (secara berurut) karena 1) petani memilih berkebun kelapa sawit 2) areal perladangan semakin sempit karena terbitnya izin konsesi perusahaan 3) adanya larangan membakar hutan dan lahan dan 4) sumber penghasilan utama masyarakat beralih dari ladang ke bidang perkayuan, seperti mencari kayu chip untuk dijual ke perusahaan. Berbeda dengan di Kampung Olak, petani di Kampung Sungai Rawa berhenti berladang karena 1) serangan hama seperti babi dan burung, yang merusak tanaman ladang 2) sumber penghasilan utama masyarakat beralih dari ladang ke bidang perkayuan, seperti mencari kayu ke hutan 3) petani mulai tidak kompak berladang 4) intrusi air asin atau air laut yang mempengaruhi pertumbuhan tanaman, dan 5) terdapat sumber beras yang bisa dibeli dari daerah luar di sekitarnya.

Praktik perladangan telah lama ditinggalkan petani, yaitu selama lebih dari satu dasawarsa di Kampung Olak dan lebih dari tiga dasawarsa di Kampung Sungai Rawa. Perubahan perladangan menjadi perkebunan tidak hanya terjadi di Kampung Olak dan Sungai Rawa. Perladangan juga telah lama ditinggalkan oleh masyarakat Kampung Karo di Desa Kuta Gamber yang umumnya bercocok tanam menetap dengan irigasi, berkebun tembakau dan penggunaan pupuk yang meluas dalam praktik pertaniannya (Singarimbun, 1984). Setelah tidak berladang, masyarakat Desa Kuta Gamber memenuhi kebutuhan pangan berupa padi dari sawah yang mengandalkan irigasi.

\section{Praktik Perkebunan}

Perkebunan merupakan praktik pertanian yang dilakukan petani setelah tidak berladang. Praktik perkebunan umumnya dilakukan dengan menanam komoditas kelapa sawit dan karet. Kelapa sawit merupakan komoditas perkebunan yang paling banyak ditanam. Hasil penelitian menunjukkan bahwa hampir 2/3 dari jumlah responden Kampung Olak dan lebih dari 1/2 dari jumlah responden Kampung Sungai Rawa menanam kelapa sawit di lahannya. Adapun komoditas tanaman utama lainnya di Kampung Olak yaitu karet, sedangkan komoditas tanaman utama lainnya di Kampung Sungai Rawa yaitu sagu, karet, kelapa dan nenas seperti terlihat pada Gambar 1.

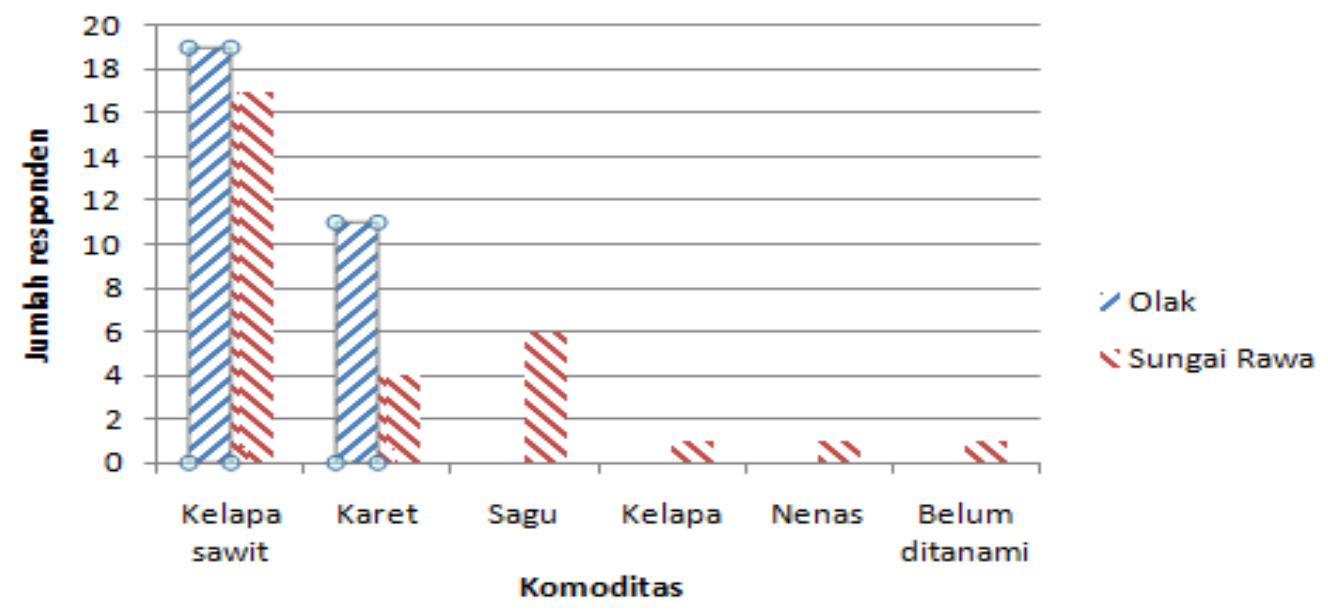

Gambar 1 Komoditas perkebunan responden 
Penggunaan api masih dipraktikkan dalam kegiatan penyiapan lahan perkebunan. Pada penelitian ini digunakan istilah teknologi sederhana dan teknologi moderen. Penyiapan lahan dengan teknologi sederhana yaitu penyiapan lahan dengan penggunaan api, sedangkan penyiapan lahan dengan teknologi moderen yaitu penyiapan lahan tanpa penggunaan api. Penyiapan lahan perkebunan dilakukan petani dengan menggunakan teknologi sederhana dan teknologi moderen. Penyiapan lahan menggunakan teknologi sederhana dilakukan oleh $46.67 \%$ dari jumlah responden Kampung Olak dan $56.67 \%$ dari jumlah responden Kampung Sungai Rawa, hal ini juga berarti bahwa adopsi teknologi moderen dilakukan oleh $53.33 \%$ dari jumlah responden Kampung Olak dan $43.33 \%$ dari jumlah responden Kampung Sungai Rawa. Kebakaran lahan di Kampung Olak dan Sungai Rawa dialami oleh petani yang menyiapkan lahan perkebunan baik yang menggunakan teknologi sederhana maupun teknologi moderen.

Adopsi teknologi moderen lebih banyak dilakukan petani Kampung Olak dibandingkan dengan petani Kampung Sungai Rawa. Petani pada kedua kampung memiliki alasan berbeda dalam mengadopsi teknologi moderen. Pada praktik penyiapan lahan perkebunan, terdapat dua bentuk teknologi moderen. Pertama, penyiapan lahan tanpa penggunaan api, petani hanya menggunakan peralatan manual seperti parang, cangkul dan kapak. Kedua, penyiapan lahan tanpa penggunaan api, petani menggunakan alat berat. Petani memiliki alasan untuk mengadopsi teknologi moderen tersebut. Alasan paling penting petani Kampung Olak mengadopsi teknologi moderen, dengan menggunakan peralatan manual antara lain 1) takut ditangkap/dipidana jika membersihkan lahan dengan cara membakar 2) petani hanya memiliki peralatan manual seperti parang, kapak, dan cangkul 3) tidak ada biaya untuk membersihkan lahan dengan menggunakan alat berat 4) biaya murah, dan 5) tidak ada kayu yang besar-besar di lahan sehinggabisa ditebang dengan peralatan manual. Alasan yang digunakan petani Kampung Olak tidak jauh berbeda dengan alasan petani Kampung Sungai Rawa. Alasan paling penting petani Kampung Sungai Rawa mengadopsi teknologi moderen, dengan menggunakan peralatan manual antara lain: 1) takut ditangkap/dipidana jika membersihkan lahan dengan cara membakar 2) petani hanya memiliki peralatan sederhana seperti parang, kapak dan cangkul 3) tidak ada biaya untuk membersihkan lahan dengan menggunakan alat berat 4) lahan yang dibersihkan petani umumnya berupa belukar. Penyiapan lahan menggunakan peralatan manual dengan alasan tersebut menunjukkan bahwa petani memiliki keterbatasan dalam penyiapan lahan. Keterbatasan ini juga menunjukkan bahwa masyarakat memiliki keterbatasan pengetahuan untuk alternatif-alternatif penyiapan lahan tanpa bakar (Syaufina dan Sukmana 2010).

Adopsi teknologi moderen dengan menggunakan alat berat juga dilakukan sebagian petani. Alasan paling penting petani Kampung Olak mengadopsi teknologi moderen, menggunakan alat berat antara lain: 1) takut ditangkap/dipidana jika membersihkan lahan dengan cara membakar 2) lahan lebih bersih karena alat berat bisa membersihkan kayu-kayu besar, dan 3) mendapat bantuan alat berat untuk membersihkan lahan. Sebaliknya, tidak ada petani Kampung Sungai Rawa mengadopsi teknologi moderen menggunakan alat berat. Penggunaan teknologi moderen dengan menggunakan alat berat membutuhkan biaya sewa alat berat sebesar 5-7 juta rupiah/ha, sehingga banyak petani tidak sanggup untuk menggunakan alat berat pada penyiapan lahan perkebunan. Petani tidak memiliki biaya untuk menyewa alat berat, menunjukkan sulitnya penggunaan alat berat pada tingkat petani. Bantuan alat berat dalam penyiapan lahan untuk masyarakat memerlukan instruksi kepada perusahaan perkebunan untuk memberikan bantuan bagi kelompok masyarakat dengan meminjamkan alat berat (Syaufina 2014). Penyiapan lahan perkebunan menggunakan alat berat dilakukan dengan membuat jalur-jalur tanam. Antara jalur-jalur tanam tersebut, terdapat gundukan yang merupakan sisa material pembersihan yang letaknya searah dan sepanjang jalur tanam. Penelitian ini juga menunjukkan bahwa petani memiliki alasan utama melakukan adopsi teknologi karena petani takut ditangkap atau dipidana apabila melakukan penyiapan lahan dengan teknologi sederhana yaitu penggunaan api.

Umumnya petani melakukan penyiapan lahan perkebunan tidak secara bergotong-royong. Pada penelitian ini terdapat dua tipe organisasi. Pertama, organisasi gotong-royong yaitu penyiapan lahan perkebunan yang dilakukan baik secara gotong-royong maupun tolong-menolong. Kedua, tidak berorganisasi yaitu penyiapan lahan perkebunan yang dilakukan sendiri atau mengupahkan pekerjaannya kepada orang lain. Tidak seperti 
praktik perladangan, penyiapan lahan pada praktik perkebunan dengan bergotong-royong tidak banyak dilakukan oleh petani. Penyiapan lahan dengan organisasi gotong-royong dilakukan oleh $13.33 \%$ dari jumlah responden Kampung Olak dan $6.67 \%$ dari jumlah responden Kampung Sungai Rawa, hal ini juga berarti adopsi tidak berorganisasi dilakukan oleh $86.67 \%$ dari jumlah responden Kampung Olak dan $93.33 \%$ dari jumlah responden Kampung Sungai Rawa.

Praktik penyiapan lahan perkebunan yang dilakukan dengan tidak berorganisasi membedakan alasan petani yang mengerjakan penyiapan lahan sendiri dan penyiapan lahan dengan mengupahkan pekerjaannya kepada orang lain. Adopsi tidak berorganisasi umumnya dilakukan petani di kedua kampung. Adopsi lebih banyak dilakukan petani Kampung Sungai Rawa dibandingkan dengan petani di Kampung Olak. Alasan paling penting petani Kampung Olak mengadopsi tidak berorganisasi dengan mengerjakan sendiri antara lain: 1) tidak ada biaya 2) lahan yang dikerjakan tidak luas 3) menghemat dan meringankan biaya 4) sedikit proses dalam pekerjaan sehingga bisa dikerjakan sendiri 5) adanya larangan membakar hutan dan lahan. Sebaliknya alasan paling penting petani Kampung Sungai Rawa mengadopsi tidak berorganisasi dengan mengerjakan sendiri antara lain: 1) tidak ada biaya 2) pekerjaan dilakukan dengan berangsur-angsur 3) setiap orang sudah fokus mengerjakan lahannya masing-masing 4) pekerjaan merupakan sumber nafkah 5) lahan yang dikerjakan merupakan lahan milik sendiri.

Petani yang mengadopsi tidak berorganisasi dengan mengupahkan pekerjaannya kepada orang lain memiliki alasan yang berbeda dengan alasan-alasan di atas. Alasan paling penting petani Kampung Olak mengadopsi tidak berorganisasi dengan mengupahkan pekerjaan antara lain: 1) tidak memiliki waktu karena kesibukan 2) banyaknya proses dalam pekerjaan sehingga diupahkan 3) petani tidak sanggup melakukannya sendiri karena memiliki lahan yang luas. Sebaliknya alasan paling penting petani Kampung Sungai Rawa mengadopsi tidak berorganisasi dengan mengupahkan pekerjaan antara lain: 1) petani tidak sanggup melakukannya sendiri karena memiliki lahan yang luas 2) tidak memiliki waktu karena kesibukan 3) petani mengupahkan apabila ada uang untuk membayar upah 4) jarak lahan yang jauh dari tempat tinggal.

Perubahan organisasi gotong-royong menjadi tidak berorganisasi tidak terjadi pada semua kegiatan masyarakat. Perubahan terjadi pada bidang pertanian. Petani lebih banyak melakukan pekerjaan pertanian secara sendiri termasuk sistem upah. Sebagian petani sudah mampu mengupahkan pekerjaan di lahannya kepada orang lain. Proses pergeseran sistem gotong-royong menjadi sistem sewa menyewa buruh tani juga terjadi di daerah lain, seperti di Jawa karena terdorong oleh murahnya tenaga buruh tani (Koentjaraningrat, 1984).

\section{Dampak Praktik Perladangan dan Perkebunan terhadap Kebakaran Hutan dan Lahan}

Kebakaran hutan dan lahan tidak terjadi pada masa perladangan, karena pembakaran dalam penyiapan lahan perladangan dilakukan dengan menerapkan pengetahuan lokal masyarakat. Penerapan pengetahuan lokal pada perladangan dalam menyiapkan lahan sudah mulai berkurang terutama dalam penyiapan lahan perkebunan. Hal ini disebabkan oleh erosi pengetahuan dan praktek tradisional tentang cara membakar yang aman sebagai akibat dari erosi rasa kerukunan anggota masyarakat yang disebabkan dampak modernisasi dan gelombang migrasi dari luar (KemenegLH dan UNDP 1998).

Kebakaran hutan dan lahan di Kabupaten Siak dan kabupaten-kabupaten lainnya di Provinsi Riau terjadi hampir setiap tahun. Kebakaran tersebut menimbulkan kerusakan lingkungan dan kerugian baik secara ekologi, ekonomi, sosial budaya dan politik. Kebakaran hutan dan lahan dapat disebabkan secara alami dan perbuatan manusia. Hal ini dijelaskan lebih lanjut oleh KemenegLH dan UNDP (1998) bahwa penyebab kebakaran hutan dan lahan seperti kebakaran yang tidak disengaja dan kebakaran yang disengaja. Kebakaran baik yang disengaja maupun yang tidak disengaja tersebut berkaitan dengan manusia. Berbagai penelitian menunjukkan bahwa kebakaran hutan dan lahan diakibatkan oleh perbuatan manusia. Penelitian Mapilata et al. (2003) menunjukkan bahwa aktivitas manusia merupakan faktor pemicu yang berpengaruh nyata terhadap kebakaran hutan dan lahan yang terjadi di Palangkaraya. Aktivitas manusia dalam mengelola lahan misalnya 
berupa pembukaan lahan untuk kegiatan pertanian, perkebunan, atau penggunaan lahan lainnya. Penelitian Syaufina (2014) menyatakan bahwa penyebab utama kebakaran yang terjadi di Provinsi Riau adalah kegiatan pembukaan lahan untuk perkebunan dan pertanian.

Praktik perladangan di Kampung Olak bukan penyebab terjadinya kebakaran hutan dan lahan. Pembakaran dilakukan pada penyiapan lahan ladang. Petani menjaga ladangnya pada saat melakukan pembakaran, sehingga api hanya membakar lokasi calon ladang. Tidak berbeda dengan Kampung Olak, perladangan di Kampung Sungai Rawa juga bukan penyebab terjadinya kebakaran hutan dan lahan. Perladangan berakhir pada tahun 1980, pada waktu-waktu tersebut tidak pernah tercatat adanya peristiwa kebakaran hutan dan lahan, kecuali kegiatan pembakaran untuk penyiapan ladang namun tidak menyebabkan meluasnya api sampai keluar ladang.

Pada tahun 2017 sampai saat penelitian dilakukan tidak ada kejadian kebakaran hutan dan lahan di Kampung Olak dan Sungai Rawa. Kebakaran lahan yang dialami responden Kampung Sungai Rawa terjadi pada rentang tahun 1990-2015, sedangkan di Kampung Olak pada tahun 2007 seperti pada Gambar 2 dan 3.

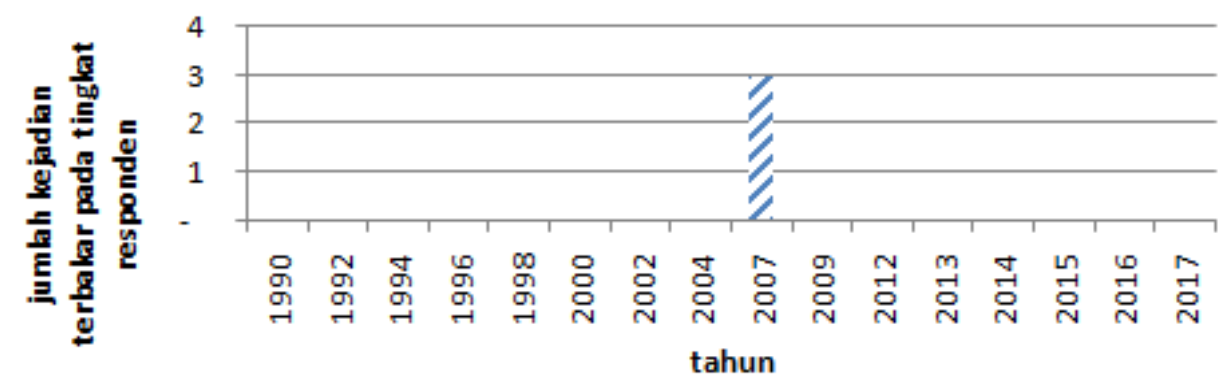

Gambar 2 Kejadian lahan terbakar pada tingkat responden Kampung Olak (1990-2017)

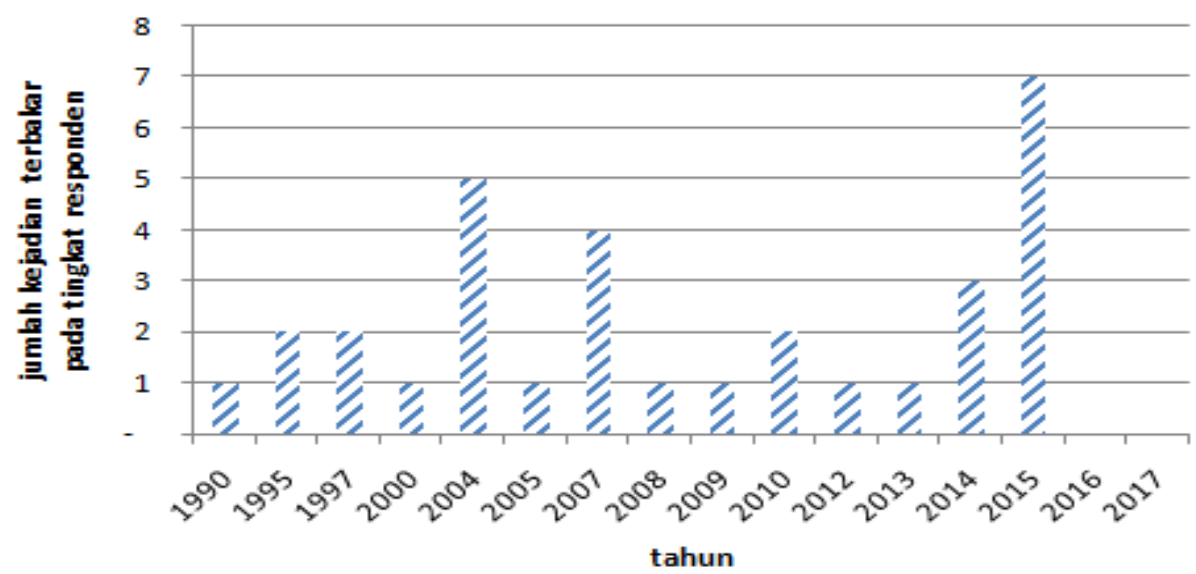

Gambar 3 Kejadian lahan terbakar pada tingkat responden Kampung Sungai Rawa (1990-2017)

Perladangan berakhir pada tahun 2005 di Kampung Olak dan tahun 1980 di Kampung Sungai Rawa. Gambar 2 dan 3 memperlihatkan bahwa kebakaran lahan responden di Kampung Olak terjadi pada tahun 2007, sedangkan di Kampung Sungai Rawa mulai terjadi pada tahun 1990. Kebakaran lahan terjadi ketika petani melakukan praktik perkebunan. Kebakaran lahan umumnya disebabkan oleh api yang merembet dari penyiapan lahan perkebunan yang dilakukan dengan cara membakar. Penelitian ini menunjukkan bahwa perladangan bukan penyebab terjadinya kebakaran hutan dan lahan.

Hasil analisis rank spearman memperlihatkan bahwa nilai koefisien korelasi penggunaan teknologi responden petani Kampung Olak dengan tingkat kebakaran lahan pada taraf uji $99 \%$ adalah $(r s=0.089)$. Ini artinya korelasi antara penggunaan teknologi dengan tingkat kebakaran lahan sangat lemah, sedangkan nilai koefisien korelasi penggunaan teknologi responden petani Kampung Sungai Rawa dengan tingkat kebakaran lahan pada taraf uji $99 \%$ adalah $(r s=-0.321)$. Ini artinya korelasi antara penggunaan teknologi dengan tingkat 
kebakaran lahan pada penyiapan lahan perkebunan cukup dan tidak searah. Kebakaran lahan di Kampung Olak dan Sungai Rawa tidak ditentukan oleh penggunaan teknologi sederhana dan moderen pada penyiapan lahan perkebunan milik petani. Kebakaran lahan dialami oleh petani, baik petani yang menggunakan teknologi sederhana dan petani yang menggunakan teknologi moderen.

Hasil analisis rank spearman memperlihatkan bahwa nilai koefisien korelasi antara tipe organisasi penyiapan lahan responden petani Kampung Olak dengan tingkat kebakaran lahan pada taraf uji $99 \%$ adalah ( $r s=0.196)$. Ini artinya korelasi antara tipe organisasi dengan tingkat kebakaran lahan sangat lemah. Hasil tersebut tidak jauh berbeda dengan nilai koefisien korelasi antara tipe organisasi penyiapan lahan responden petani Kampung Sungai Rawa dengan tingkat kebakaran lahan pada taraf uji $99 \%$ adalah ( $r s=-0.234)$. Ini artinya korelasi antara tipe organisasi dengan tingkat kebakaran lahan pada penyiapan lahan perkebunan sangat lemah dan tidak searah. Kebakaran lahan di Kampung Olak dan Sungai Rawa tidak ditentukan oleh penyiapan lahan yang dilakukan dengan organisasi gotong-royong atau tidak berorganisasi. Kebakaran lahan dialami oleh petani, baik petani yang bergotong-royong dan petani yang tidak berorganisasi.

Hasil penelitian menunjukkan bahwa kebakaran lahan bukan disebabkan petani mengadopsi teknologi dan organisasi, karena kebakaran terjadi baik pada petani yang mengadopsi maupun tidak mengadopsi teknologi dan organisasi pada penyiapan lahan perkebunan. Penggunaan teknologi moderen pada penyiapan lahan perkebunan seperti tidak menggunakan api, menggunakan peralatan manual seperti parang, cangkul, kapak, penggunaan round-up, dan penggunaan alat berat. Penggunaan round-up merupakan salah satu perubahan teknologi pada perkebunan. Perkebunan merupakan bentuk praktik pertanian menetap. Pertanian menetap memerlukan pengolahan tanah yang lebih intensif (Steward 1955).

\section{Alasan-alasan Pendorong Perubahan}

Kelapa sawit merupakan komoditas perkebunan yang paling banyak ditanam oleh petani pada kedua kampung. Pengetahuan berkebun kelapa sawit didapatkan bukan melalui pelatihan yang berkaitan dengan komoditas tersebut, namun pengetahuan tersebut berawal dari pendatang yang menanam kelapa sawit serta perusahaan perkebunan baik yang beroperasi di kedua kampung dan di kampung sekitarnya. Keberhasilan pengelolaan kebun kelapa sawit oleh pendatang diikuti oleh para petani dengan menanam kelapa sawit di lahannya. Petani yang terlebih dahulu menanam kelapa sawit diikuti oleh petani lainnya. Petani yang belakangan menanam kelapa sawit mendapatkan pengetahuan dari petani yang lebih dahulu menanam. Pengetahuan diperoleh melalui diskusi dan kunjungan ke kebun kelapa sawit yang telah ditanami dengan tujuan untuk mengetahui cara penanaman, mendapatkan bibit dan sebagainya.

Penelitian ini menunjukkan alasan petani memilih berkebun (kelapa sawit) antara lain: 1) hasil panen kelapa sawit melebihi dari komoditas perkebunan yang lain 2) penjualan tandan buah segar (TBS) kelapa sawit relatif mudah, karena pembeli datang ke petani untuk menjemput hasil panen 3) pekerjaan tidak rumit, hanya dilakukan dua kali dalam sebulan 4) hasil panen kelapa sawit tidak dipengaruhi oleh cuaca, yaitu tetap memberikan hasil panen, baik pada musim hujan atau kemarau 5) bibit kelapa sawit mudah diperoleh 6) hampir seluruh petani berkebun kelapa sawit. Alasan-alasan memilih berkebun kelapa sawit juga ditunjukkan oleh petani di Desa Rambahan Kabupaten Kuantan Singingi Provinsi Riau dalam pemilihan komoditas kelapa sawit dengan alasan: budidayanya tidak membutuhkan pemeliharaan yang berat; pemanenan hasilnya dapat dilakukan setiap hari dengan pendapatan yang lebih tinggi daripada karet; hasilnya mudah dijual; dan petani mempunyai pengetahuan tata cara budidayanya (Suharjito 2011). 


\section{KESIMPULAN}

Penyiapan lahan pada praktik perladangan dilakukan dengan menggunakan teknologi sederhana berupa penggunaan api yang umumnya dilakukan secara gotong-royong. Penggunaan teknologi sederhana berupa penggunaan api masih banyak dilakukan petani dalam penyiapan lahan perkebunan, meskipun sebagian kecil petani telah mengadopsi teknologi moderen berupa penggunaan alat berat. Alasan utama petani mengadopsi teknologi moderen, yaitu petani takut ditangkap atau dipidana apabila melakukan penyiapan lahan perkebunan dengan menggunakan api.

Penyiapan lahan perladangan yang umumnya dilakukan secara gotong-royong tidak banyak lagi dilakukan petani dalam penyiapan lahan perkebunan. Perubahan praktik perladangan menjadi perkebunan menunjukkan perubahan pada organisasi sosial. Penyiapan lahan perkebunan umumnya dilakukan secara perorangan dan sistem upah.

Kebakaran lahan tidak terjadi pada masa praktik perladangan. Periode masa perladangan dan tahun-tahun terjadinya kebakaran hutan dan lahan menunjukkan bahwa praktik perladangan tidak menyebabkan terjadinya kebakaran hutan dan lahan. Kebakaran lahan yang terjadi pada praktik perkebunan menunjukkan bahwa penyiapan lahan perkebunan merupakan salah satu penyebab terjadinya kebakaran hutan dan lahan.

\section{DAFTAR PUSTAKA}

[DitPKHL] Direktorat Pengendalian Kebakaran Hutan dan Lahan Kementerian Lingkungan Hidup dan Kehutanan. 2017. Data kebakaran hutan dan lahan di Indonesia. Jakarta.

[KemenegLH] Kementerian Negara Lingkungan Hidup dan [UNDP] United Nations Development Programme. 1998. Ringkasan Eksekutif Kebakaran Hutan dan Lahan di Indonesia. Jakarta.

Adiputra AB, Barus. 2018. Analisis risiko bencana kebakaran hutan dan lahan di Pulau Bengkalis. Jurnal Geografi Edukasi dan Lingkungan. 1(2):55-62.

Ahmad MM. 2000. Dinamika pengetahuan lokal dalam mengelola sumber daya hutan dan lahan rawa pada masyarakat di sekitar areal kebakaran (Studi kasus di Desa Talang Batu, Kecamatan Mesuji, Kabupaten Tulang Bawang, Propinsi Lampung. Skripsi. Bogor: Institut Pertanian Bogor.

Amril AJ. 2009. Strategi pengendalian kebakaran Hutan di IUPHHK-HA. Tesis. Bogor: Sekolah Pascasarjana, Institut Pertanian Bogor.

Cooley F. 1984. Allang, Sebuah Desa di Pulau Ambon. Dalam Masyarakat Desa di Indonesia. Koentjaraningrat, editor. Jakarta: Lembaga Penerbit Fakultas Ekonomi Universitas Indonesia Ed ke-2.

Dove MR. 1985. Sistem Perladangan di Indonesia, Suatu Studi-Kasus dari Kalimantan Barat. Yogyakarta: Gadjah Mada University Press.

Evayanti T dan Zulkarnaini. 2014. Partisipasi organisasi masyarakat peduli api (MPA) terhadap pencegahan dan pengendalian kebakaran hutan dan lahan di Kabupaten Pelalawan. Jurnal Ilmu Lingkungan. 8(1):111.

Goethals PR. 1984. Rarak: Sebuah Desa Peladangan di Sumbawa Barat. Dalam Masyarakat Desa di Indonesia Ed ke-2. Koentjaraningrat, editor. Jakarta: Lembaga Penerbit Fakultas Ekonomi Universitas Indonesia.

Hanifah M, Syaufina L, dan Prasasti I. 2016. Deteksi area bekas kebakaran hutan dan lahan menggunakan data citra resolusi menengah modis dengan pendekatan indeks kebakaran. Jurnal Pengelolaan Sumberdaya Alam dan Lingkungan. 6(1):77-85.

Hudson AD, Hudson JM. 1984. Telang: Sebuah Desa Ma'anyan di Kalimantan Tengah Dalam Masyarakat Desa di Indonesia. Koentjaraningrat Ed ke-2. editor. Jakarta: Lembaga Penerbit Fakultas Ekonomi Universitas Indonesia. 
Irjayani IK. 2000. Tinjauan beberapa aspek sosial ekonomi dan budaya masyarakat dalam kegiatan pertanian tradisional di Desa Kabuaena Kecamatan Angkaisera Kabupaten Yapen Waropen. Skripsi. Manokwari: Universitas Cendrawasih.

Koentjaraningrat. 1984. Masyarakat Desa di Indonesia. Dalam Masyarakat Desa di Indonesia. Koentjaraningrat, editor. Lembaga Penerbit Fakultas Ekonomi Universitas Indonesia. Jakarta. Ed ke2.

Kuswandi A. 2006. Teknik pembakaran dalam penyiapan lahan ladang berpindah di kawasan HTI PT. Finnantara Intiga Resor Entanjan Kabupaten Sanggau Provinsi Kalimantan Barat. Skripsi. Bogor: Institut Pertanian Bogor.

Mapilata E, Gandasasmita K, dan Djajakirana G. 2013. Analisis daerah rawan kebakaran hutan dan lahan dalam penataan ruang di Kota Palangkaraya Provinsi Kalimantan Tengah. Globe15. 178-184.

Marzali A. 2005. Antropologi dan Pembangunan Indonesia. Jakarta: Kencana Prenada Media Group.

Molyoutami E, van Noordwijk M, Sakuntaladewi N, Agus F. 2010. Perubahan Pola Perladangan: Pergeseran persepsi mengenai para peladang di Indonesia. Bogor: ICRAF.

Pardosi J, Asngari PS, Tarumingkeng RC, Susanto D, dan Sumarjo. 2005. Pemberdayaan peladang berpindah: Kasus Kabupaten Kutai Kartanegara, Kabupaten Kutai Timur, dan Kabupaten Kutai Barat di Provinsi Kalimantan Timur. Jurnal Penyuluhan. 1(1):33-40.

Prasasti I, Boer R, Ardiansyah M, Buono A, Syaufina L, dan Vetrita Y. 2012. Analisis hubungan kode-kode SPBK (sistem peringkat bahaya kebakaran) dan hotspot dengan kebakaran hutan dan lahan di Kalimantan Tengah. Jurnal Pengelolaan Sumberdaya Alam dan Lingkungan. 2(2):91-101.

Purnomo H, Shantiko B, Sitorus S, Gunawan H, Achdiawan R, Kartodihardjo H, dan Dewayani AA. 2017. Fire economy and actor network of forest and land fires in Indonesia. Forest Policy and Economics. 2131.

Rachmawati N, Susilawati. 2012. Upaya masyarakat dalam mencegah kebakaran pada saat pembukaan lahan di Desa Gunung Sari Kecamatan Pulau Laut Utara Kabupaten Kotabaru. Enviro Scienteae8. 35-44.

Rasyid F. 2014. Permasalahan dan dampak kebakaran hutan. Jurnal Lingkar Widyaiswara. 1(4):47-59.

Rogers EM. 1983. Diffusion of Innovation. New York: Free Press.

Saharjo BH. 2016. Pengendalian Kebakaran Hutan dan atau Lahan Indonesia. Bogor: PT Penerbit IPB Press.

Silalahi U. 2012. Metode Penelitian Sosial Cetakan ke-3. Bandung: PT Refika Aditama.

Singarimbun M. 1984. Kuta Gamber: Sebuah Kampung Karo. Dalam Masyarakat Desa di Indonesia. Koentjaraningrat, editor. Jakarta: Lembaga Penerbit Fakultas Ekonomi Universitas Indonesia, Ed ke-2.

Steward JH. 1955. Theory of Culture Change. Urbana: University of Illinois Press.

Suharjito D. 2011. Tradisi dan perubahan budi daya pohon di Desa Rambahan Kuansing dan Desa Ranggang Tanah Laut. Jurnal Manajemen Hutan Tropika. 17(3), pp. 95-102.

Syaufina L. 2008. Kebakaran Hutan dan Lahan di Indonesia: Perilaku Api, Penyebab, dan Dampak Kebakaran. Bayumedia Publishing, Malang.

Syaufina L. 2014. Peran strategis sektor pertanian dalam pengendalian kebakaran lahan gambut. Risalah Kebijakan Pertanian dan Lingkungan. pp. 35-39.

Syaufina L, Sukmana A. 2010. Tinjauan Penyebab Utama Kebakaran Hutan di Daerah Tangkapan Air Danau Toba: ITTO PROJECT PD 394/06 REV.1 (F) Centre of Forest and Nature Conservation Research and Development. 